\title{
PREPARATION AND CHARACTERIZATIONS OF LATEX/FILLER NANOCOMPOSITES
}

\author{
Mohamad Firdaus OMar ${ }^{1,2}$, Nuriah MOHAMad ${ }^{2}$ ANd Fathilah Binti Ali ${ }^{1 *}$ \\ ${ }^{I}$ Department of Biotechnology Engineering, Faculty of Engineering, International \\ Islamic University Malaysia, Jalan Gombak, 53100 Kuala Lumpur, Malaysia.
}

${ }^{2}$ Top Glove Sdn. Bhd., R\&D Centre, Lot 64593, Jalan Dahlia KU/8, 41050 Klang, Selangor, Malaysia

"Corresponding author: fathilah@iium.edu.my

(Received: $9^{\text {th }}$ March 2020; Accepted: $14^{\text {th }}$ June 2020; Published on-line: $4^{\text {th }}$ July 2020)

\begin{abstract}
Latex compounding which incorporates various types of clays as filler to the rubber can significantly give reinforcement in the rubber matrix when rubber/clay nanocomposites are formed, but the filler agglomerates. Thus, study was conducted by using Kaolin clay as the filler in the rubber nanocomposites with silane coupling agent to functionalize the surface of the filler. This study was done in order to investigate the mechanical properties of various functionalized Kaolin in latex nanocomposites, to prepare various ratios of Kaolin to rubber, and to characterize mechanical, thermal and morphological properties of the Kaolin in latex nanocomposites. To achieve these, six types of silane coupling agents was used for Kaolin filler surface functionalization purpose during the filler's incorporation in latex compounding. The optimized coupling agent, USi7301 ( $\gamma$-chloropropyltrimetoxysilane) - with tensile strength value of $32.77 \mathrm{MPa}$, elongation at break value of $632.589 \%$ and force at break value of $6.737 \mathrm{~N}$ - was used to further functionalize Kaolin filler in different ratios so as to achieve the optimum mechanical, thermal and morphological properties of the filler in the polymer matrix. Universal tensile machine was used to analyze the mechanical properties of the nanocomposites, while the Scanning Electron Microscopy (SEM) and Differential Scanning Calorimetry (DSC) were used to observe the morphological and thermal properties of the nanocomposites, respectively. The results showed that reducing the Total Solids Content (TSC) of Kaolin filler to $26 \%$ somehow showed the optimized properties of the nanocomposites, giving 34.00 MPa tensile strength, $576.494 \%$ elongation at break and $6.564 \mathrm{~N}$ force at break. Rough surface morphology was observed under SEM suggesting the occurrence of phase separation between the hydrophilic filler and the hydrophobic rubber matrix. In the DSC plot, sample with USi-7301 and with functionalized Kaolin filler $26 \%$ TSC showed glass transition temperature shifted to lower region compared to normal nitrile rubber. The reinforcement of nanocomposites formed will not only enhance the properties of the nanocomposites, but is also economically feasible thus brings advantages to the industry.
\end{abstract}

ABSTRAK: Penyebatian lateks yang menggabungkan pelbagai jenis tanah liat sebagai pengisi dalam getah dapat memberi pengukuhan dalam matriks getah dengan ketara apabila nanokomposit getah / tanah liat terbentuk, tetapi pengisi mengagregat. Oleh itu, kajian dijalankan dengan menggunakan tanah liat Kaolin sebagai pengisi dalam nanokomposit getah dengan ejen gandingan silan untuk menambah-fungsi permukaan pengisi tersebut. Kajian ini dilakukan untuk mengenalpasti sifat mekanik pelbagai Kaolin (yang berfungsi) dalam nanokomposit lateks, untuk menyediakan pelbagai nisbah Kaolin terhadap getah, dan untuk mencirikan sifat mekanik, haba dan morfologi Kaolin dalam nanokomposit lateks. Untuk mencapainya, enam jenis ejen gandingan silan digunakan 
untuk tujuan menambah-fungsi permukaan pengisi Kaolin semasa penggabungan pengisi dalam penyebatian lateks. Ejen gandingan silan yang paling optimum, USi-7301 ( $\gamma$-silan kloropropiltrimetoksi) - dengan nilai kekuatan tegangan $32.77 \mathrm{MPa}$, nilai pemanjangan ketika pemutusan $632.589 \%$ dan kekuatan daya ketika pemutusan $6.737 \mathrm{~N}$ - digunakan dengan lebih lanjut untuk menambah-fungsi pengisi Kaolin dalam nisbah yang berbeza untuk lebih mencapai sifat mekanikal, haba dan morfologi optimum pengisi dalam matriks polimer lateks. Mesin tegangan universal digunakan untuk menganalisis sifat mekanik nanokomposit, sementara Mikroskopi Elektron Pengimbasan (SEM) dan Kalorimetri Pengimbasan Berbeza (DSC) digunakan untuk menganalisa sifat morfologi dan haba nanokomposit tersebut. Hasil kajian menunjukkan bahawa pengurangan Jumlah Kandungan Pepejal (TSC) pengisi Kaolin kepada 26\% menunjukkan sifat optimum nanokomposit, dengan kekuatan tegangan $34.00 \mathrm{MPa}$, pemanjangan ketika pemutusan sebanyak $576.494 \%$ dan daya ketika pemutusan sebanyak 6.564 N. Morfologi permukaan kasar diperhatikan di bawah SEM dan ia menunjukkan berlakunya pemisahan fasa antara pengisi hidrofilik dan matriks getah hidrofobik. Dalam plot DSC, sampel dengan USi7301 dan dengan pengisi Kaolin yang difungsikan dengan 26\% TSC menunjukkan suhu peralihan kaca beralih ke kawasan yang lebih rendah berbanding getah nitril biasa. Pengukuhan nanokomposit yang terbentuk bukan sahaja akan meningkatkan sifat nanokomposit, tetapi juga dapat dilaksanakan secara ekonomi sehingga memberi banyak kelebihan kepada industri.

KEY WORDS: rubber; latex; filler; nanocomposites; silane coupling agent

\section{INTRODUCTION}

The incorporation of clay with natural rubber has been commonly investigated in the past few years because of the structure of the nanoparticles exhibited that can significantly give reinforcement towards rubber/clay nanocomposites when the two materials are mixed [1]. Due to its improved physical or mechanical properties, thermal stability, gas permeability and so on, these rubber/clay nanocomposites have gained so much attention, especially in the rubber industry. Compared to unfilled rubber compounds, these rubber/clay nanocomposites are generally better in properties as mentioned. As the name suggests, nanocomposites are lighter in terms of weight and significantly is low cost.

There are several methods on how these nanocomposites could be formed; which include melt intercalation [2], in-situ polymerization process [3], intercalation of solution [4], and also the compounding of latex [5]. Latex compounding and melt mixing methods have been combined and rampantly used especially in the rubber industry [5], since it is considerably more environmental-friendly because no organic solvents are present in the system and has high compatibility with the system that is currently used in industries. The idea of latex compounding is that, during the initial stage of the process, the clay interlayer spacing is increased. During this stage, monomers form polymers due to the clay dispersion in the water that was happening and thus intercalation of matrix will happen within the widened spacing of the clay [6].

However, because nanocomposite itself is in nano-scale, agglomerations of particles of the filler tend to happen and therefore, the adhesion and compatibility of the filler with the polymer matrix need to be enhanced. It was proposed in this project that silane coupling agent could help in modifying the filler surface so as to induce a strong interaction between the polymer and filler, by silanization process. This process is significant in order to introduce reactions on the surface of hydroxyl $(-\mathrm{OH})$ groups abundant on the mineral (filler) 
surface with the coupling agent [7]. Therefore, surface-functionalized filler was created in this project and believed to have improved the properties of the polymer from its matrix.

In this study, Kaolin filler was used as the main material, surface-functionalized with six coupling agents separately in order to investigate the best type of coupling agent to be employed in its latex compounding to produce synthetic rubber gloves. Furthermore, the surface-functionalized filler at the optimized coupling agent type - would then be prepared with different ratios or total solids content (TSC) to find the best optimized ratio or TSC for the filler for improved mechanical, morphological and thermal properties of the rubber produced.

The importance of this study is to improve the mechanical properties of synthetic rubber that will be produced with the incorporation of surface functionalized latex/filler nanocomposites from Kaolin clay as the main ingredient for filler. From the past recent studies, it has been shown that Kaolin filler could be one of the contributing agents in rubber production, during the latex compounding procedure. The present study is carried out in order to achieve the objectives as follows; to prepare Kaolin clay surface functionalized with different functionalization agents incorporated with Nitrile Butadiene Rubber (NBR) synthetic rubber and to investigate the mechanical properties of the various functionalized Kaolin filler in latex nanocomposites, to prepare various ratios or TSC of Kaolin filler to latex based on the optimized functionalized Kaolin, and to characterize mechanical, thermal and morphological properties of the optimized Kaolin filler in latex nanocomposites.

\section{MATERIALS AND METHODS}

\subsection{Materials}

Carboxylated nitrile butadiene rubber latex (NBR latex) was used as the core material to produce the rubber samples. Kaolin clay was used as the main constituents for Kaolin filler for the latex/filler nanocomposites purpose. For functionalization of the filler, six (6) silane coupling agents of product names USi-2301, USi-7301, USi-7311, USi-1212, USi1302 and USi-5301 were used for the surface functionalization of Kaolin filler. After characterized by tensile test, USi-7301 has the highest elongation at break value, thus chosen to be the optimized sample. Then, this coupling agent is used for surface functionalization of Kaolin filler to be diluted to different ratios or TSC.

The raw chemicals for the Kaolin filler preparation as well as latex compound preparation as in Table 1 and Table 2 together with the aforementioned coupling agents in were obtained from Top Glove Sdn. Bhd via Avidco Asia Pacific Sdn. Bhd. as Top Glove's main supplier for chemicals that were purchased from China.

\subsection{Kaolin Filler Preparation}

The ingredients were mixed in a tank and stirred to produce a homogenous mixture and left to mature for 24-36 hours. Kaolin filler of appropriate mass to be used in few sets of latex compounding was made and a small portion of the filler was taken and diluted where necessary for latex compounding procedure (Table 1). 
Table 1: Ingredients in preparing Kaolin filler

\begin{tabular}{cc}
\hline Ingredient (Chemical) & Mass percentage (\%) \\
\hline pH adjuster & $<4$ \\
Dispersing agent & $1-5$ \\
Wetting agent & $<1$ \\
Thickener & $1-2$ \\
Antifoam & $<1$ \\
Water & $60-65$ \\
Calcined Kaolin clay & 35 \\
\hline
\end{tabular}

\subsection{Latex Compounding}

TSC, measured in percentage, was measured as the remaining weight of sample after drying, expressed in terms of the original weight of the wet sample as in Eq. 1.

$\operatorname{TSC} \%=\left[\frac{\text { (weight of dry sample+container)-(weight of empty container) }}{\text { (weight wet sample+container)-(weight empty container) }}\right] \times 100 \%$

The dosage of each chemical was measured in phr. In rubber industry, it is common to use this term to demonstrate the amount of chemicals needed to be incorporated with the raw latex for compounding purpose. Thus, the mass of each chemical with regards to their given dosage values in phr unit was as in Eq. 2.

chemical mass $(\mathrm{kg})=\left[\frac{\text { latex mass }(\mathrm{kg}) \times \text { chemical dosage }(\mathrm{phr}) \times \text { latex TSC }}{\text { chemical TSC }}\right] \times 100 \%$

Table 2 shows the chemical formulation for the production of nitrile gloves with required dosage (phr) of each chemical. NBR latex, as the main ingredient for the synthetic glove samples production was initially stirred in the compounding tank based on its required amount. Then, the chemicals as in Table 2 were mixed with the raw latex. The compounded latex was then stirred for maturation purpose for 24-36 hours. The TSC of the compounded latex will then be checked upon maturation for clarification. The mixture was further diluted with water if necessary. Then, the samples were produced by hand-dip procedure in the production line.

Table 2: Formulation of NBR latex added with Kaolin filler and coupling agent

\begin{tabular}{ccc}
\hline Ingredient (Chemical) & TSC (\%) & Dosage (phr) \\
\hline NBR latex & $\mathbf{4 4 . 5}$ & $\mathbf{1 0 0}$ \\
Kaolin filler & $\mathbf{3 5 . 0}$ & $\mathbf{7 . 0}$ \\
& $\begin{array}{c}\text { (Variable in second } \\
\text { objective) }\end{array}$ & \\
Coupling agent & $\mathbf{1 0 0}$ & $\mathbf{0 . 3}$ \\
pH adjuster & 25 & $1.4-2.0$ \\
Vulcanizing Accelerator & 50 & $0.2-0.8$ \\
Vulcanizing agent & 60 & $0.8-1.4$ \\
Vulcanizing activator & 60 & $1.0-1.6$ \\
Wax & 49 & $0.5-1.0$ \\
Wetting agent & 25 & $0.2-0.4$ \\
Antifoam & 10 & $0.02-0.06$ \\
\hline
\end{tabular}




\subsection{Methods of Testing and Characterizations}

The nitrile glove samples were produced in the factory's production line by hand-dip procedure. Hand-dip was done by plugging out of the hand-shapped ceramic mould before the latex dip process to be dipped in the lab scale-made compounded latex for 8-10 seconds before plugging in back to the production line. The ceramic mould temperature shall maintain its temperature in between 55 to $70{ }^{\circ} \mathrm{C}$ throughout the hand-dip process. The dipped moulds shall undergone processes such as leaching, chlorination, drying and cuffbeadrolling before stripping of the samples. Then, the glove samples were cut into dumbbell-shape by using the pneumatic cutter before tested for tensile properties (tensile strength, elongation at break, force at break). Universal tensile machine (Model: Al-3000) from Top Glove company was used for this purpose. Scanning Electron Microscope (SEM) was used to observe the morphological properties of the samples. The fractured surface of the samples was observed with Field Emission SEM (FESEM) (JOEL, JFC-1600) from IIUM, after the tensile test was done. The fractured samples were initially cut to an approximately $4 \mathrm{~mm} \times 4 \mathrm{~mm}$ square shape and placed on the sample holder with the fractured surface facing upward. The microphotographs of the samples were generated at the magnification $\times 2300$. Thermal properties of the samples were analyzed by using Differential Scanning Calorimetry (DSC) (METTLER TOLEDO DSC 3) from Top Glove, with heating rate of $10.0^{\circ} \mathrm{C} / \mathrm{min}$, temperature range of $-75^{\circ} \mathrm{C}$ to $350{ }^{\circ} \mathrm{C}$ nitrogen gas, and a one-time heat process. The samples were cut into an approximately $2.0 \mathrm{mg}$.

\section{RESULTS AND DISCUSSION}

\subsection{Tensile Properties}

\subsubsection{Sample Tensile Properties with Different Silane Coupling Agents}

Figure 1 shows tensile properties (tensile strength and elongation at break) for rubber samples incorporated with Kaolin filler functionalized with different silane coupling agents. It can be seen that the samples have the highest average tensile strength after the incorporation of USi-7311 (chloro family) silane coupling agent at $35.47 \mathrm{MPa}$, while the average tensile strength is the lowest with USi-1302 (amino family) silane coupling agent at only $28.24 \mathrm{MPa}$, when they were compared with the control samples. This could be due to the stronger bonding between the matrix and nanoparticles presented in the samples with USi-7311 compared to others [8]. USi-7301 of chloro family has elongation at break value of $632.589 \%$ as well as considerably high tensile strength of $32.77 \mathrm{MPa}$. Here, polymer chains are believed to cross-link with each other that eventually strengthen the polymeric structure. Occasionally, the event leads to higher stress needed to elongate and rupture the sample that gives high elongation at break value [9]. The tested samples generally conform to the ASTD D639 standard requirement of minimum tensile strength and elongation at break of $14 \mathrm{MPa}$ and $500 \%$ respectively. 

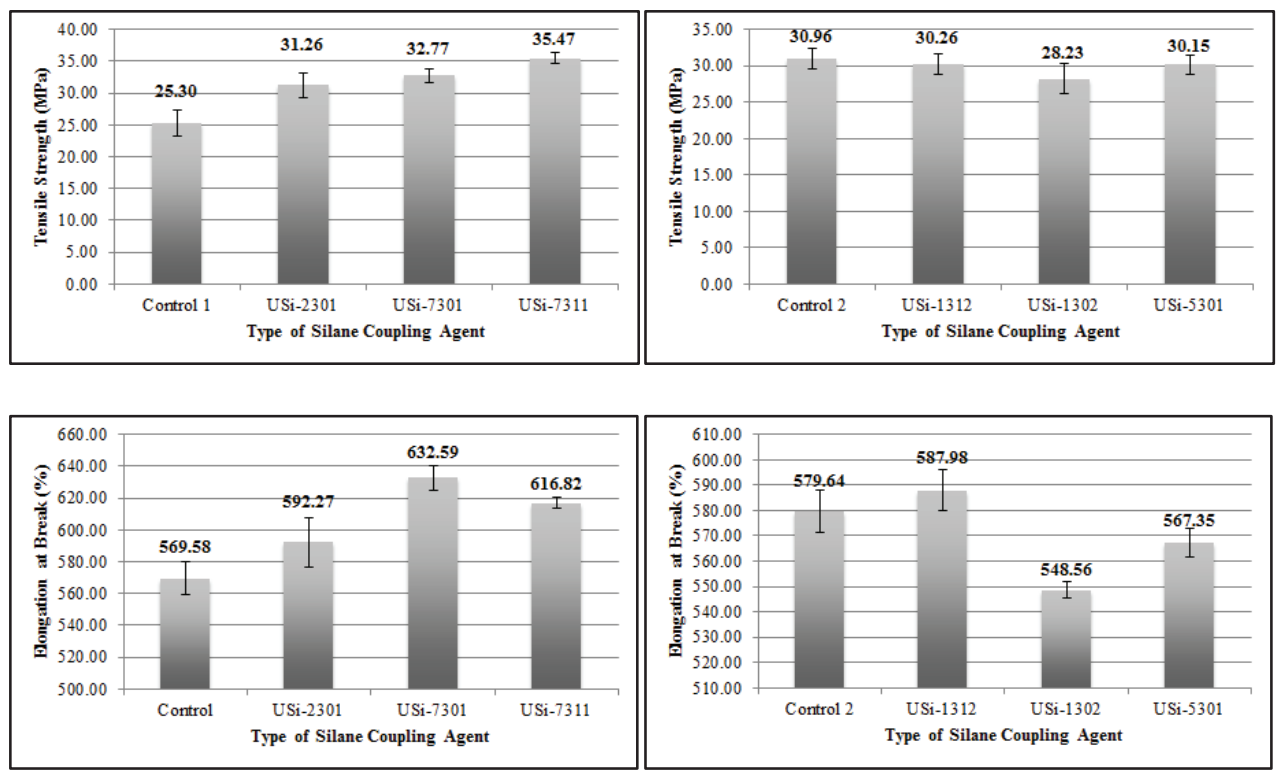

Figure 1: Tensile properties of rubber with Kaolin filler functionalized with different silane coupling agent.

\subsubsection{Sample Tensile Properties with Different TSC of Kaolin Filler}

The best optimized silane coupling agent used for the $35 \%$ Kaolin filler is of type USi7301 with tensile strength value of $32.77 \mathrm{MPa}$ and elongation at break value of $632.589 \%$. This silane was further used to be incorporated with Kaolin filler of various TSC values (35, 32, 29, 26 and $23 \%$ ). Figure 2 shows the results for tensile properties (tensile strength and elongation at break) for rubber samples incorporated with different ratios or TSC Kaolin filler functionalized with USi-7301 silane coupling agent.

From Figure 2, all sets showed increase in the rubber's tensile strength relatively with filler addition at decreasing solids content. Theoretically, better spreading of the silane coupling agent used throughout the filler surface occurs here since the solids content is lower to achieve better silane spreading on the filler surface, thus the rubber's tensile strength improved [10].

The average elongation at break for the samples at $35 \%$ TSC of filler is much lower than the ones with lower TSCs, and $23 \%$ TSC of Kaolin filler loadings with the highest elongation at break value of $587.248 \%$. At this Kaolin filler's TSC, it is believed that the polymer chains gives better cross-link with each other and stronger the polymeric structure which in turns giving higher stress needed to elongate and rupture the sample [8].
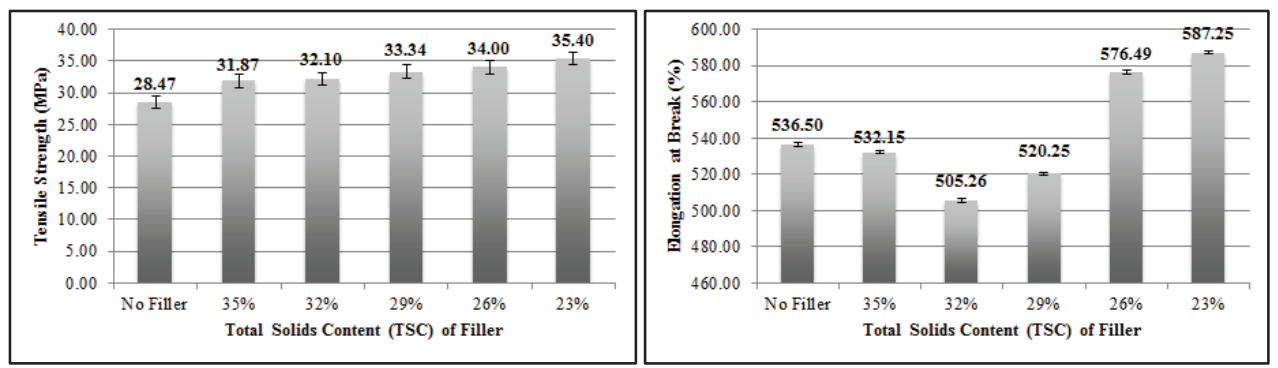

Figure 2: Tensile properties of rubber with optimized silane coupling agent in different ratios (TSC) of Kaolin filler. 


\subsection{Morphological Properties}

Four (4) samples as follows were taken for characterization under SEM to analyze their surface morphology and filler behavior in the rubber matrix, respectively: (i) rubber sample without fillers, (ii) rubber sample with Kaolin filler but without silane coupling agent, (iii) rubber sample with Kaolin filler functionalized with USi-7301 silane, and (iv) rubber sample with Kaolin filler of $26 \%$ TSC functionalized with USi-7301. Figure 3 shows FESEM analysis on the four samples under $2300 \times$ magnification.

As can be observed from Figure 3, the surfaces can be justified to be smooth in Figure 4 (a) and (b), but rough in (c) and (d). With the presence of silane coupling agent USi-7301 (Figures 4 (c) and (d)), a better adhesion between Kaolin filler and rubber matrix were believed to happen here. Kaolin filler well wetted by the rubber matrix and the pulled out of filler from rubber matrix is minimum [11]. These figures also show that the surface has many tear lines with branching. This type of failure indicates strong adhesion between filler and rubber matrix. However, the film is rougher than the control rubber sample with more pronounced undulating curves. Particles are very obviously accompanied by cracks and grooves. The formation of surface cracks suggests the occurrence of phase separation between the hydrophilic filler and the hydrophobic rubber matrix [12].

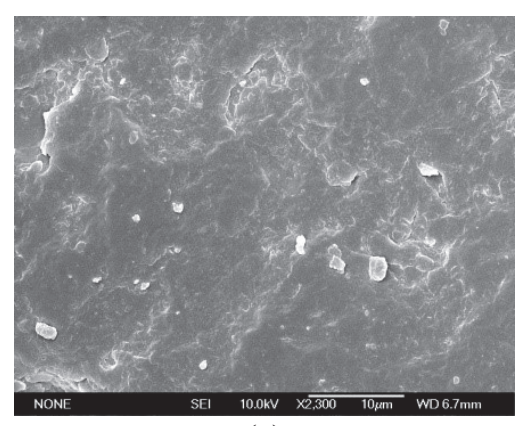

(a)

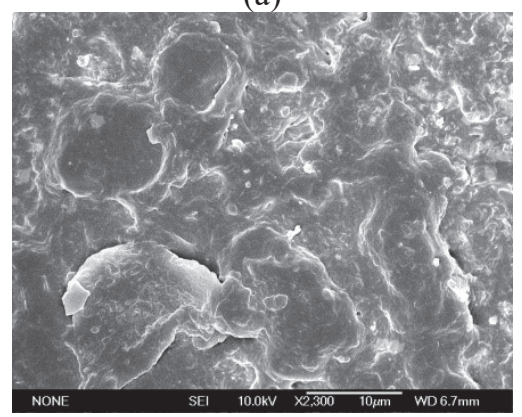

(c)

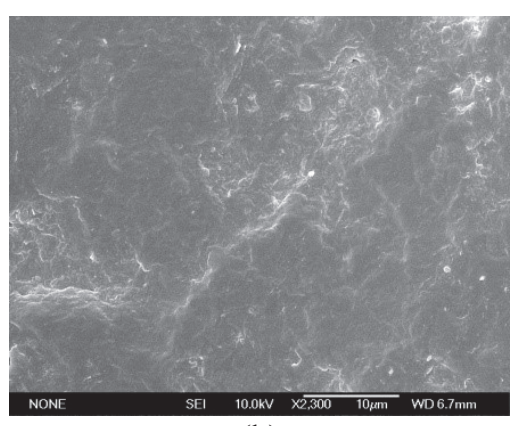

(b)

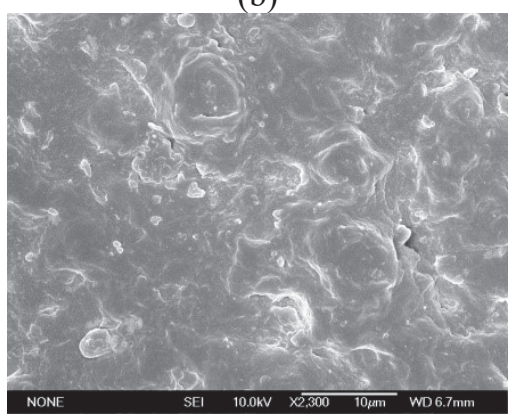

(d)

Figure 3: SEM images of the control $(a, b)$ and the optimized samples $(c, d)$ at $\times 2300$ magnification.

\subsection{Thermal Properties}

The same 4 samples were taken for characterization in analyzing their thermal properties by using DSC. The results were based on the use of DSC on graph plotting. Table 3 shows the results of thermal analysis of the samples, with respective glass-transition temperatures $\left(T_{\mathrm{g}}\right)$. 
Table 3: $T_{\mathrm{g}}$ values of samples in DSC analysis.

\begin{tabular}{lcc}
\hline \multicolumn{1}{c}{ Sample } & $\begin{array}{c}\boldsymbol{T}_{\mathbf{g}} \text { value } \\
\left({ }^{\circ} \mathbf{C}\right)\end{array}$ & $\begin{array}{c}\text { Decomposition } \\
\text { Temperature }\left({ }^{\circ} \mathbf{C}\right)\end{array}$ \\
\hline $\begin{array}{l}\text { Rubber sample without fillers } \\
\text { Rubber sample with Kaolin filler but } \\
\text { without silane coupling agent }\end{array}$ & -20.67 & 244.88 \\
$\begin{array}{l}\text { Rubber sample with Kaolin filler } \\
\text { functionalized with USi-7301 silane }\end{array}$ & -19.62 & 241.80 \\
$\begin{array}{l}\text { Rubber sample with Kaolin filler of 26 } \\
\text { \% TSC functionalized with USi-7301 }\end{array}$ & -20.98 & 240.19 \\
\hline
\end{tabular}

From the results in the DSC curve tabulated in Table 3, on further heating the samples, the sudden shifting down of the 4 curves indicate that there is more heat flow. The onset temperature value for sample with USi-7301 silane has the absolute $T_{\mathrm{g}}$ value of $-20.98{ }^{\circ} \mathrm{C}$. Thus, there is more in the heat capacity of the sample compared to the others. In contrast, the sample without silane coupling agent functionalizing the filler has the lowest absolute $T_{\mathrm{g}}$ value $-19.62{ }^{\circ} \mathrm{C}$. Apparently, all the samples had gone through glass transition, and the change in heat capacity is more on the sample with USi-7301. However, the change doesn't occur suddenly, but takes place over a temperature range.

The curve also had shown no crystallization peak, which means the polymer cannot form crystals. Apparently, for nitrile rubber, it is amorphous, thus the samples will not show any crystallization or any melting behavior $[13,14]$. Towards the end of the plots, the highest decomposition temperature is for the sample containing no filler, at $244.88^{\circ} \mathrm{C}$, and the lowest decomposition temperature $236.30^{\circ} \mathrm{C}$ achieved for the samples with Kaolin filler TSC of $26 \%$ functionalized with USi-7301 silane coupling agent. The samples are rendered safe to be used for handling materials at relatively high temperature.

\section{CONCLUSION}

In this study, one of the fillers that have the potential to be further employed and commercialized in rubber or polymer industry - the Kaolin filler, from its clay based - was prepared and characterized with silane coupling agent and optimized. USi-7301 silane coupling agent was taken to be the optimized functionalization agent with tensile strength value of $32.77 \mathrm{MPa}$ and elongation at break value of 632.589. Optimized content of $26 \%$ TSC Kaolin filler in the rubber composites has exhibited tensile strength value of $34.00 \mathrm{MPa}$ and elongation at break value of $576.494 \%$. USi-7301 and Kaolin filler TSC of $26 \%$ showed rough surface morphology with glass transition temperature of $-20.98^{\circ} \mathrm{C}$ and -20.80 ${ }^{\circ} \mathrm{C}$ respectively. This sample can further be explored for its potential in the gloves production.

\section{ACKNOWLEDGEMENT}

The corresponding author would like to thank IIUM Faculty of Engineering and Top Glove Sdn. Bhd. and its R\&D department for the supports in accomplishing this project. Not to forget, also thanks to Top Glove's main chemical and equipment suppliers for this project for samples preparation and characterizations. Top Glove company, the world's largest rubber glove manufacturer had also provided space in their production line for the samples' production. 


\section{REFERENCES}

[1] Mohd Nor, N. A., Muttalib, S. N., \& Othman, N. (2016). Synthesis of Natural Rubber/Palygorskite Nanocomposites via Silylation and Cation Exchange. Nanoclay Reinforced Polymer Composites, 261-289. doi:10.1007/978-981-10-1953-1_12A.

[2] Lu, M., Zhou, J., Wang, L., Zhao, W., Lu, Y., Zhang, L., \& Liu, Y. (2010). Design and Preparation of Cross-Linked Polystyrene Nanoparticles for Elastomer Reinforcement. Journal of Nanomaterials, 2010, 1-8. doi:10.1155/2010/352914.

[3] Okamoto, M., Morita, S., Taguchi, H., Kim, Y. H., Kotaka, T., \& Tateyama, H. (2000). Synthesis and structure of smectic clay/poly(methyl methacrylate) and clay/polystyrene nanocomposites via in situ intercalative polymerization. Polymer, 41(10), 3887-3890. doi:10.1016/s0032-3861(99)00655-2.

[4] Paul, P. K., Hussain, S. A., Bhattacharjee, D., \& Pal, M. (2013). Preparation of polystyreneclay nanocomposite by solution intercalation technique. Bulletin of Materials Science, 36(3), 361-366. doi:10.1007/s12034-013-0498-4.

[5] Tan, J., Wang, X., Luo, Y., \& Jia, D. (2012). Rubber/clay nanocomposites by combined latex compounding and melt mixing: A masterbatch process. Materials \& Design, 34, 825-831. doi:10.1016/j.matdes.2011.07.015.

[6] Mohd Nor, N. A., Muttalib, S. N., \& Othman, N. (2016). Synthesis of Natural Rubber/Palygorskite Nanocomposites via Silylation and Cation Exchange. Nanoclay Reinforced Polymer Composites, 261-289. doi:10.1007/978-981-10-1953-1_12.

[7] Tatou, M., Genix, A., Imaz, A., Forcada, J., Banc, A., Schweins, R., ... Oberdisse, J. (2011). Reinforcement and Polymer Mobility in Silica-Latex Nanocomposites with Controlled Aggregation. Macromolecules, 44(22), 9029-9039. doi:10.1021/ma2012893

[8] Nassar, A., \& Nassar, E. (2013). Study on Mechanical Properties of Epoxy Polymer Reinforced with NanoSiC particles. Nanoscience and Nanoengineering, 1(2), 89-93. https://doi.org/10.13189/nn.2013.010201.

[9] Nair, K. P., Nair, A. B., \& Joseph, R. (2014). Carboxylated acrylo nitrile butadiene rubber latex/kaolin nanocomposites: preparation and properties. Composite Interfaces, 21(6), 571583. doi:10.1080/15685543.2014.899198.

[10] Takatoh, K., Sakamoto, M., Hasegawa, R., Koden, M., Itoh, N., \& Hasegawa, M. (2005). Alignment Technology and Applications of Liquid Crystal Devices, 90-95. Boca Raton: CRC Press.

[11] Alkadasi, N. A., Sarwade, B. D., Hundiwale, D. G., \& Kapadi, U. R. (2004). Studies on the effect of titanate coupling agent $(2.0 \%)$ on the mechanical properties of flyash-filled polybutadiene rubber. Journal of Applied Polymer Science, 93(3), 1293-1298. doi:10.1002/app.20548.

[12] A. Ndabigengesere, K. B. Narasiah, and K. Subraimanian. "Quality of water treated by coagulation using Moringa oleifera seeds," Water Res. Vol. 32, no. 3, pp. 781-791, 1998.

[13] Song, Q., Tan, Z., Zhang, Y., Sha, L., Deng, X., Deng, Y., ... Yang, L. (2014). Do the rubber plantations in tropical China act as large carbon sinks? iForest - Biogeosciences and Forestry, 7(1), 42-47. doi:10.3832/ifor0891-007.

[14] Shanks, R. A., \& Kong, I. (2013). General Purpose Elastomers: Structure, Chemistry, Physics and Performance. Advanced Structured Materials, 11-45. doi:10.1007/978-3-642-20925-3_2. 